This item was submitted to Loughborough's Research Repository by the author.

Items in Figshare are protected by copyright, with all rights reserved, unless otherwise indicated.

\title{
Negotiating Cold War culture at the crossroads of East and West: uplifting the working people, entertaining the masses, cultivating the nation
}

PLEASE CITE THE PUBLISHED VERSION

http://journals.cambridge.org/

\section{PUBLISHER}

Cambridge University Press (๑ Society for the Comparative Study of Society and History)

VERSION

AM (Accepted Manuscript)

\section{LICENCE}

CC BY-NC-ND 4.0

\section{REPOSITORY RECORD}

Mihelj, Sabina. 2019. "Negotiating Cold War Culture at the Crossroads of East and West: Uplifting the Working People, Entertaining the Masses, Cultivating the Nation”. figshare. https://hdl.handle.net/2134/8496. 
This item was submitted to Loughborough's Institutional Repository (https://dspace.lboro.ac.uk/) by the author and is made available under the following Creative Commons Licence conditions.

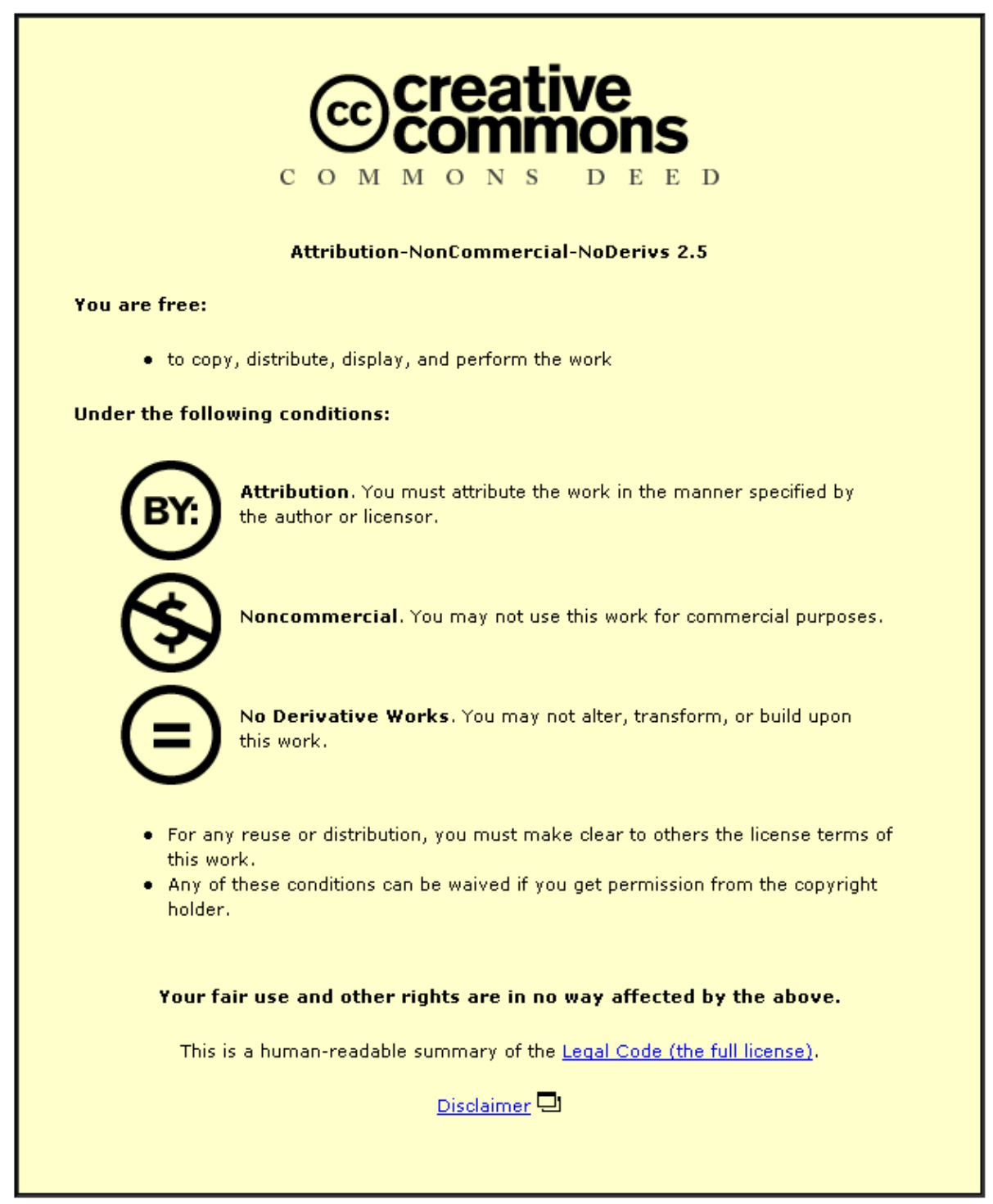

For the full text of this licence, please go to: http://creativecommons.org/licenses/by-nc-nd/2.5/ 
September 2010, Version accepted for publication, before editing/proofreading.

\title{
Negotiating Cold War Culture at the Crossroads of East and West: Uplifting the Working People, Entertaining the Masses, Cultivating the Nation ${ }^{1}$
}

Sabina Mihelj, Department of Social Sciences, Loughborough University, UK

E-mail: $\underline{\text { S.Mihelj@,lboro.ac.uk }}$

The final, definitive version of this paper is due to be published in Comparative Studies in Society and History 53(3), July 2011, by Cambridge University Press (C) Society for the Comparative Study of Society and History). It is available at: http://journals.cambridge.org/.

\begin{abstract}
Over the past two decades, the notion of the Cold War as a bipolar conflict has come under increasing strain, and several authors have pointed to aspects of Cold War reality that eschew the logic of binary distinctions and categories. While these points are well taken, we should be weary of dismissing Cold War binaries as mere myth. Instead, this paper argues for the need to take these binary distinctions and categories seriously as an object of analysis, treat them as elements of 'practical knowledge' (Bourdieu), and acknowledge their constitutive role in negotiating the relationships between ideological projects and everyday realities. Such and approach is particularly valuable when dealing with categories and normative distinctions that continue to circulate in journalistic and scholarly discourse today - including East/West, socialism /capitalism, elite/mass etc. - and that have in the meantime
\end{abstract}

\section{Notes}

Acknowledgments: This research was supported by the British Academy (SG43957). I would like to thank Reana Senjković and the three anonymous reviewers of $\mathrm{CSSH}$ for their comments on earlier versions of this paper. Parts of this paper were presented at the workshop Cultures of the Cold War (Sheffield 2008) and at the conference Divided Dreamworlds: The Cultural Cold War in the East and West (Utrecht 2008). 
accrued new meanings and functions. To demonstrate this, the paper examines the journalistic discourse about culture in the north-western part of Yugoslavia. Focusing on two distinct periods - the late 1940s and the early 1970s - it shows how the journalistic discourse about culture was used to position Yugoslav culture both geopolitically and historically, construct its internal hierarchies, as well as negotiate those elements of the local reality that were at odds with official identity narratives.

Keywords: Cold War, culture, discourse, Yugoslavia, Italy 
Since the Berlin Wall came down in 1989 our understanding of Cold War history has changed considerably. The new wave of research, spurred by the opening of archives and opportunities for novel East-West comparisons, threw into sharper relief aspects of the Cold War contest that had previously received little attention. It was becoming increasingly clear that the Cold War was not only a military, political and economic conflict, but one that was profoundly implicated in, and shaped by, key transformations in twentieth century culture. ${ }^{2}$ Capitalizing on the increased accessibility of primary sources from former socialist states, recent research also provided valuable insights into the politics of everyday culture on both sides of the Iron Curtain, ${ }^{3}$ and we have also seen the publication of several transnational accounts of the cultural Cold War spanning both the West and the East. ${ }^{4}$

This growing body of work has raised a number of wider conceptual and methodological issues. It questioned the value of understanding the socialist period as a 'deviation' from the supposedly normal course of historical development, and highlighted the continuities between post-1945 cultural histories and long-term historical trends, including the rise of modernity, popular sovereignty and mass culture. This literature also brought to light some of the structural similarities between the developments in the East and the West, and thereby questioned the value of understanding the Cold War as a bipolar divide, as well as the usefulness of thinking about socialism and capitalism in binary terms. In line with this,

\footnotetext{
${ }^{2}$ E.g. Stephen J. Whitfield, The Culture of the Cold War (Baltimore: Johns Hopkins University Press, 1991); Frances Stonor Saunders, Who Paid the Piper? The CIA and the Cultural Cold War (London: Granta, 1999); and Walter L. Hixson, Parting the Curtain: Propaganda, Culture and the Cold War, 1945-1961 (New York: St. Martin's Press, 1996); Shiela Fitzpatrick, The Cultural Front: Power and Culture in Revolutionary Russia (Ithaca: Cornell University Press, 1992); Stephen Kotkin, Magic Mountain: Stalinism as a Civilization (Berkely: University of California Press, 1997).

${ }^{3}$ E.g. Susan E. Reid and David Crowley, eds., Style and Socialism: Modernity and Material Culture in PostWar Eastern Europe (Oxford and New York: Berg, 2000); David Lloyd Hoffmann, Stalinist Values: The Cultural Norms of Soviet Modernity, 1917-41 (Ithaca: Cornell University Press, 2003).

${ }^{4}$ E.g. Susan Buck-Morss, Dreamworld and Catastrophe. The Passing of Mass Utopia in the East and West (Cambridge and London: MIT Press, 2000); David Caute, The Dancer Defects: The Struggle for Cultural Supremacy during the Cold War (Oxford and New York: Oxford University Press, 2003); Uta G. Poiger, Jazz, Rock, and Rebels: Cold War Politics and American Culture in a Divided Germany (Berkeley, Los Angeles and London: University of California Press, 2000).
} 
several recent studies have argued for the importance of unpacking the logic of Cold War discourse, its historical roots and epistemic effects, as well as its continuing hold on scholarly and journalistic imagination. According to Alexei Yurchak, the binary categories that remain widespread in much of academic and journalistic writing about Soviet socialism - such as the state and the people, oppression and resistance, official and unofficial culture - cannot capture the complexity of values, ideals and realities of the Soviet system, within which 'control, coercion, alienation, fear, and moral quandaries were irreducibly mixed with ideals, communal ethics, dignity, creativity, and care for the future'. ${ }^{5}$ Dominic Boyer's examination of dialectical knowledge in and its multiple figurations at work in twentieth-century German culture employs a compatible analytical approach, drawing attention to the constitutive role of dialectical thinking and knowing in shaping German modern culture. ${ }^{6}$ Among other things, Boyer traces the reshaping of the East/West distinction in the two Germanys, arguing that actors on each side of the Cold War divide drew on the East-West binary to displace the moral burden of Nazism onto the 'other' Germany, and then examines the strategic uses of the same distinction - now laden with new meanings - among media practitioners in postunification Germany. ${ }^{7}$

Post-World War II Yugoslavia provides an apposite case study for a further reflection on the trajectories and politics of Cold War discourse and its role in shaping both the culture of the period as well as our ways of knowing it. The developments that followed Yugoslavia's expulsion from Cominform in 1948 sit uneasily with the implicit East-West divide that underpins much of the Cold War historiography. Its 'market socialism' is often seen as a compromise between socialist planning and free enterprise, and its involvement in the Non-

\footnotetext{
${ }^{5}$ Alexei Yurchak, Everything Was Forever, until it Was No More: The Last Soviet Generation (Princeton: Princeton University Press, 2006), p. 10.

${ }^{6}$ Dominic Boyer, Spirit and System: Media, Intellectuals, and the Dialectic of Modern German Culture (Chicago: The University of Chicago Press, 2005).

${ }^{7}$ Ibid., pp. 181-270.
} 
Aligned Movement can be interpreted as an articulation of the same compromise in the field of foreign policy. ${ }^{8}$ The same is true of Yugoslav culture: while initially adopting Soviet cultural policies, ${ }^{9}$ Yugoslavia's writers, artists and other cultural producers soon started carving out a 'third way' between what they saw as the excessively state-controlled model of cultural production followed in the East, and the overly market-led approach favored in the West. ${ }^{10}$ It is tempting to describe these developments in terms of an encounter or struggle between the 'Soviet', 'totalitarian' or 'Eastern' model and the 'capitalist', 'liberal' or 'Western' model of social organization. Indeed, such an approach is evident in the vast majority of existing literature on the cultural history of socialist Yugoslavia. Aleš Gabrič, whose work focuses on the changing cultural policies in Slovenia in the period between 1953 and 1963, discusses these changes in terms of a gradual movement away from the 'Soviet' or 'Stalinist' model of social organization, associated with direct party control over cultural production, towards a distinctly Yugoslav type of socialism, characterized by less rigid forms of party influence and a greater tolerance of diverse cultural forms and values. ${ }^{11}$ Predrag Marković, whose research spans from 1948 to 1965 and focuses on the Yugoslav capital of Belgrade, rejects the notion of an authentic, autochthonous Yugoslav road as a myth, and prefers to describe Yugoslav culture as a 'field of struggle' between Eastern and Western cultural influences. ${ }^{12}$ Reana Senjković, whose study analyses selected aspects of popular

\footnotetext{
${ }^{8}$ E.g. Denison Rusinow, The Yugoslav Experiment, 1948-1974 (Berkeley: University of California Press, 1977); Alvin Z. Rubinstein, Yugoslavia and the Nonaligned World (Princeton: Princeton University Press, 1970).

${ }^{9}$ Ljubodrag Dimić, Agitprop kultura: Agitpropovska faza kulturne politike u Srbiji 1945-1952. godine (Beograd: Rad, 1988); Aleš Gabrič, Slovenska agitpropovska kulturna politika: 1945-1952 (Ljubljana: Mladika, 1991); Carol S. Lilly, Power and Persuasion: Ideology and Rhetoric in Communist Yugoslavia, 1944-1953 (Boulder, CO: Westview Press, 2001), 1-160.

${ }^{10}$ Studies that trace various aspects of this transformation include Petar Luković, Bolja prošlost. Prizori iz muzičkog života Jugoslavije 1940-1989 (Beograd: Mladost, 1989); Aleš Gabrič, Socialistična kulturna revolucija: Slovenska kulturne politika, 1953-1962 (Ljubljana: Cankarjeva založba, 1995); Predrag J. Marković, Beograd između istoka i zapada 1948-1965. godine (Beograd: Službeni list SRJ, 1996); Igor Duda, U potrazi za blagostanjem: o povjesti dokolice i potrošačkog društva u Hrvatskoj 1959-ih i 1960-ih (Zagreb: Srednja Europa, 2005); Reana Senjković, Izgubljeno u prijenosu: Pop iskustvo soc culture (Zagreb: Biblioteka nova etnografija, 2008); Andrew Baruch Wachtel, Making a Nation, Breaking a Nation: Literature and Cultural Politics in Yugoslavia (Stanford: Stanford University Press, 1998).

${ }^{11}$ Gabrič, Socialistična kulturna revolucija.

${ }^{12}$ Marković, Beograd između istoka i zapada, pp. 493-512.
} 
culture from socialist Croatia, offers a slightly different account. In her view Yugoslav popular culture was ideologically 'hybrid', marked by a 'cohabitation of at least two ideological models'. ${ }^{13}$ Another way of organizing the narrative about socialist Yugoslav culture is one that focuses on the shifting balance of nationalist antagonisms and Yugoslav unity, or 'brotherhood' and 'unity'. This kind of approach is particularly prominent in Andrew Wachtel's analysis of Yugoslav literature and cultural politics that stretches from the nineteenth century to the late twentieth century, ${ }^{14}$ but is apparent also in other works, especially those examining the characteristics of Yugoslav culture from the 1960s onward.

Such accounts are clearly compelling and provide a much needed corrective to the usual, binary accounts of Cold War culture. Yet these contributions stop short of an explicit investigation of Yugoslav Cold War discourse as such, and its constitutive role in negotiating the relationships between the ideological project of socialist Yugoslavism and the reality of cultural practices and values at the time. In contrast, this paper takes the discourse of Yugoslav socialism as its central object of analysis. Following Pierre Bourdieu's theory of practice, this discourse is understood as 'practical knowledge', produced by social actors who themselves constitute objects of analysis. ${ }^{15}$ This practical knowledge, organized around mundane, taken-for-granted categories and distinctions, was constituted by, as well as constitutive of, the reality of Yugoslav socialist culture, and should be subjected to critical scrutiny. What were the central normative assumptions, categories and distinctions at work in the practical knowledge about socialist Yugoslav culture? How did the social actors use this practical knowledge to make sense of the reality of cultural practices in the country? And

\footnotetext{
${ }^{13}$ Senjković, Izgubljeno u prijenosu, p. 174.

${ }^{14}$ Wachtel, Making a Nation.

${ }^{15}$ Pierre Bourdieu, Distinction: A Social Critique of the Judgement of Taste, translated by Richard Nice (London: Routledge and Keegan Paul, 1984), pp. 467ff.
} 
finally, what aspects of social reality did this discourse obscure, and in what ways did it help shore up or challenge the official identity narratives at the time?

To answer these questions, this paper examines the journalistic discourse about culture in the north-western part of Yugoslavia, which encompasses the eastern side of the upper Adriatic coast and the region bordering Italy. There are several reasons that make this part of Yugoslavia particularly well suited for an investigation into the functioning of Cold War framings of culture. The proximity of Italy, the bilingualism of the local population, and the presence of ethnic minorities on both sides - Italians in Yugoslavia and Slovenians in Italy encouraged constant cross-border exchanges and obstructed the processes of cultural homogenization and nation-building on each side of the border. Italian radio and later television were immensely popular with the local Yugoslav audiences, and from the 1960s onwards, shopping trips to Italy became a regular feature of everyday life. ${ }^{16}$ At the same time, many Italians and Slovenian minority members living in Italy became regular customers of Yugoslav restaurants and petrol stations, followed the radio and television broadcasts from Yugoslavia, and also formed a substantial proportion of foreign tourists visiting the Yugoslav coastal resorts. Due to these multiple cross-border ties, the region served both as a meeting point and as a battleground for competing conceptions of culture, identity and everyday life, promoted by cultural producers on both sides of the border.

\section{Cold War Culture in the North-western Yugoslavia}

To understand the full scope of these exchanges and tensions we need to keep in mind that this region forms part of the symbolic fracture that cuts the European continent, in the eyes of

\footnotetext{
${ }^{16}$ Alenka Švab, 'Consuming Western image of well-being: Shopping tourism in socialist Slovenia', Cultural Studies, Vol. 16, No. 1, 63-79 (2002); Breda Luthar, 'Remembering socialism: On desire, consumption and surveillance', Journal of Consumer Culture, Vol. 6, No. 2, 229-259 (2006).
} 
Western Europeans, into its civilized Western and underdeveloped Eastern or Balkan part. First formed in the period of Venetian Enlightenment, ${ }^{17}$ this symbolic fracture was subsequently remolded to suit the legitimating strategies and identity narratives promoted by the successive administrations in the region, including the Habsburg Empire, the Kingdom of Italy and Nazi Germany. After World War II, the older mental mappings became enmeshed with Cold War binaries, and were selectively appropriated to suit new political agendas, this time shaped by the global contest between the Soviet Union and the United States. ${ }^{18}$ Since the spreading of nationalism in the mid-nineteenth century, the successive changes of administration in the region were also accompanied by more or less violent forms of cultural homogenisation. The rise of fascism in Italy gave way to increasingly ruthless forms of Italianization of Slovenians and Croatians in the region, which in turn prompted a hardening of anti-Italian sentiments and gave rise to clandestine antifascist organizations that regularly resorted to violent means. ${ }^{19}$ Though paralleled by forms of Italo-Slav antifascist collaboration, this spiral of violence and suspicion continued throughout World War II and into the post-war period, and fostered the successive waves of (mostly Italian) emigration from the region. This history of shifting borders and ideological landscapes, intertwined with violence, prejudice and involuntary migration, gave rise to divided memories and identities that continue to shape individual recollections and collective memories in the northeastern Adriatic to this day. ${ }^{20}$ As we will see, they also had an impact on the appropriations of Cold War discourse in the region.

\footnotetext{
${ }^{17}$ Larry Wolff, Inventing Eastern Europe: The Map of Civilization on the Mind of the Enlightenment (Stanford: Stanford University Press, 1994).

${ }^{18}$ Sabina Mihelj, 'Drawing the East-West border: Narratives of modernity and identity in the north-eastern Adriatic (1947-54)', in Thomas Lindenberger, Marcus M. Payk, Bernd Stoever and Annette Vowinckel, eds., European Cold War Cultures: Perspectives on Societies in the East and West (Oxford: Berghahn Books, in press).

${ }_{19}$ Marina Cattaruzza, L'Italia e il confline orientale (Bologna: Il Mulino, 2007), pp. 168-81.

${ }^{20}$ Pamela Ballinger, History in Exile: Memory and Identity at the Borders of the Balkans (Princeton: Princeton University Press, 2002),
} 
The paper demonstrates this by examining two distinct historical periods. The first part focuses on the immediate post-World War II period up to 1948, when Yugoslav cultural policies and practices were organized in much the same way as their equivalents in the Soviet Union and elsewhere in socialist Eastern Europe. The second part first reviews some of the key changes in Yugoslav cultural policies and practices over the course of the 1950s and the 1960s, and then examines the discourse about culture in 1971, a point when the cultural field was marked by a high level of ideological diversification and by a rising tide of nationalist antagonisms.

\section{The Journalistic Discourse about Culture}

As evident from the discussion so far, this paper is concerned primarily with public discourse about culture rather than the cultural events, products or policies on themselves. In particular, it examines the normative understanding of culture promoted by the media, the distinctions and categories it relies upon, and analyzes the ways in which the press engaged with different cultural forms, including serialized novels, popular music and television series. The analysis also pays attention to the different uses of the key discursive distinctions and categories, focusing on their application in the negotiation of Yugoslav identity and culture. To asses the epistemic effects of these discursive strategies, the paper interprets them in relation to selected secondary literature about Cold War cultural practices and forms, both in Yugoslavia and beyond. The media covered in the analysis include all the major Croatian and Slovenian newspapers published in the north-western part of the federation (Riječki list/ Novi list, Glas Istre, Primorske novice), the pro-Yugoslav Slovenian minority newspaper issued in Trieste (Primorski Dnevnik), and one Italian minority newspaper (La Voce del Popolo). 
It is important to clarify the limitations imposed by the nature of primary sources used. Especially in the early post-war years, the press largely reflected official views and did not exert an independent influence on cultural processes. ${ }^{21}$ This was also a period when the literacy rates were relatively low and local resistance to communist policies fairly widespread. ${ }^{22}$ Therefore, it may well be that the framing of culture promoted by the press was largely ignored by the wider population. Accepting this proposition, however, would mean confusing influence with approval; while the socialist Yugoslav press certainly cannot be taken as an accurate expression of public culture as a whole, it nevertheless played a major role in delineating the boundaries of what was publicly acceptable, and imposing 'a structure of thinking' even among those who did not support the regime. ${ }^{23}$ Finally, taking into account the role of the media becomes even more important when examining the developments after Tito's split with Stalin in 1948 and in particular after the changes to cultural policies initiated in the early 1950s. In this period, the relative balance of power between the Party, the state, the market and the media shifted towards the latter, and the media became much more active players in the shaping of Yugoslav culture.

\section{Uplifting the working masses}

Throughout the first period examined in the paper, the border between Italy and Yugoslavia remained in flux. As the Cold War rivalry began to take shape, the territorial dispute between the two neighboring states assumed a strategically important geopolitical role, and became a

\footnotetext{
${ }^{21}$ Gertrude Joch Robinson, Tito's Maverick Media: the Politics of Mass Communications in Yugoslavia (Urbana, Chicago and London: University of Illinois Press, 1977), pp. 16-25; Lilly, Power and Persuasion, pp. 43-45.

${ }^{22}$ The analyzed newspapers, particularly those aimed at the rural population, often emphasized the need to increase the literacy rates in the region, and criticized cultural events and trends that did not conform to official guidelines.

${ }^{23}$ Cf. Jeffrey Brooks, Thank You, Comrade Stalin! Soviet Public Culture from Revolution to Cold War (Princeton: Princeton university Press, 2000), p. xiv.
} 
burning issue not only for Italy and Yugoslavia, but also for the Allied forces that took over the task of finding a solution to the 'Trieste problem'. ${ }^{24}$ Following the signing of the Paris Peace Treaty in 1947, an interim solution was implemented, which included the establishment of the Free Territory of Trieste, an unusual political formation comprising Trieste and its immediate surroundings. The legitimacy of this solution remained disputed, and much of the local population, in particular in Trieste, continued to live in a state of perpetual mass mobilization, which prompted many to emigrate to Italy and other countries. ${ }^{25}$

Operating in this volatile context, marked by the intensification of the global confrontation between the United States and the Soviet Union, the press was involved in a constant ideological battle. Along with the rest of the Yugoslav media, it formed part of a complex apparatus for cultural change, modeled on the one established in the Soviet Union and aimed at fostering the rise of a new, socialist Yugoslav culture. ${ }^{26}$ Although the Yugoslav press was legally free, and mostly not under direct ownership of the Communist Part of Yugoslavia (CPY) this apparatus nevertheless provided ample opportunities for the CPY to filter undesirable content and use the press as a collective agitator and propagandist. To start with, most major newspapers were founded by the Peoples' Front of Yugoslavia, a mass organization that shared CPY's ideological convictions. ${ }^{27}$ The Departments of Agitprop and Propaganda were regularly sending out detailed instructions on the most desirable cultural content, supplied newspapers with ready-made articles, and gave recommendations about editorial board membership. ${ }^{28}$ The CPY also used its influence over the legislative, judicial

\footnotetext{
${ }^{24}$ Glenda Sluga, The Problem of Trieste and the Italo-Yugoslav Border: Difference, Identity, and Sovereignty in Twentieth-Century Europe (Albany: State University of New York Press), pp. 133-155.

${ }^{25}$ For a detailed account of the key events, including mass demonstrations, see Bogdan C. Novak, Trieste, 1941 1954: The Ethnic, Political and Ideological Struggle (Chicago: University of Chicago Press, 1970).

${ }^{26}$ Lilly, Power and Persuasion, pp. 35-54; as well as Dimić, Agitprop kultura, and Gabrič, Slovenska agitpropovska kulturna politika.

${ }^{27}$ Božidar Novak, Hrvatsko novinarstvo u 20. stoljeću (Zagreb: Golden Marketing - Tehnička knjiga, 2005), p. 460.

${ }^{28}$ Lilly, Power and Persuasion, pp. 39-41.
} 
and executive bodies to pass and enforce legislation favorable to the Communist Party, which allowed for various indirect forms of censorship, including issuing publishing permits only to loyal publishers, boosting the circulation of party-sponsored newspapers by allocating press subsidies, and preventing the spreading of un-orthodox views by limiting the use of paper or denying access to printing facilities. ${ }^{29}$

Ideologically, the normative views about Yugoslav culture promoted by the CPY in this period were rooted in Marxist-Leninist perceptions of modernity and society, centered on the notion of culture as a tool of progress and elevation of the working classes familiar from the Soviet system of values as established in the post-revolutionary period. At the same time, these programmatic ideas were also marked by the experience of bloody intra-Yugoslav nationalist conflicts during the war and memories of inter-war Yugoslavism. Inter-war Yugoslav elites were initially intent on building a synthetic Yugoslav culture, rooted in the belief that Yugoslav peoples constituted a single national whole. ${ }^{30}$ This understanding of Yugoslavism came to be perceived by many non-Serbs as an attempt to Serbianize the country, and despite the gradual movement away from ideas of 'integral Yugoslavism' in the 1930s, inter-war Yugoslavia was subsequently remembered as an oppressive state intent on forcibly assimilating Yugoslav peoples into a single nation. ${ }^{31}$ Such selective memory constituted one of the premises that enabled the post-war Yugoslav elites to construct their project of Yugoslav nation-building as an entirely unprecedented endeavor to tie the South Slavs to a single political roof while at the same time maintaining their national distinctiveness. This twin emphasis on ideological unity and national distinctiveness embodied in the slogan 'brotherhood and unity' - formed the basis of the communist

\footnotetext{
${ }^{29}$ Robinson, Tito's Maverick Media, pp. 16-25; Lilly, Power and Persuasion, pp. 43-45.

${ }^{30}$ Wachtel, Making a Nation, pp. 67-127.

${ }^{31}$ Dejan Djokić, Elusive Compromise: A History of Interwar Yugoslavia (New York: Columbia University Press, 2007), pp. 171-222.
} 
Yugoslav nation-building project, and purportedly helped guard the new Yugoslavia against the 'mistake' committed by its interwar predecessor. ${ }^{32}$

The other key element of the post-war Yugoslav ideology was the attempt at marrying the national liberation struggle to working class struggle. According to the Yugoslav myth of origins, this union was forged during the Second World War, and found its expression in the Anti-Fascist Yugoslav People's Liberation Struggle, led by the Yugoslav Partisans. ${ }^{33}$ In line with this myth, the past anti-imperial struggles of South Slavs were now reinterpreted as struggles that were led not only by oppressed nations fighting anti-national regimes, but also by exploited working classes revolting against the bourgeoisie. Interwar Yugoslavia, went the argument, was unable to resolve intra-Yugoslav nationalist conflicts, and instead exacerbated them, largely due to continuing nationalist antagonisms between different national bourgeoisies and capitalist exploitation. ${ }^{34}$ As we will see, this blend of nationalist and communist goals proved difficult to sustain, not least because it introduced a powerful element of continuity that presented a challenge to the discursive and political attempts to create a 'new' Yugoslav culture. After all, Yugoslav socialist cultural policies continued to be underpinned by the key tropes and categories used in the pre-1945 decades, including terms like kultura or cultura (Croatian/Slovenian for culture) and narod, popolo and ljudstvo (Croatian, Italian and Slovenian for people/nation) that were burdened with the ideological baggage of nineteenth-century nation-building projects. ${ }^{35}$ The words narod, popolo and ljudstvo were particularly crucial in this respect, since they could be used to refer both to an ethnonational community as well as an ethnically diverse collective. As such, they could

\footnotetext{
${ }^{32}$ Dejan Jović, 'Communist Yugoslavia and Its 'Others', ' in Ideologies and National Identities: The Case of Twentieth century Southeastern Europe, edited by John Lampe and Mark Mazower (Budapest: CEU Press, 2004), pp. 282-285.

${ }^{33}$ Wachtel, Making a Nation, p. 133.

${ }^{34}$ Esad Zgodić, Titova nacionalna politika: temeljni pojmovi, načela i vrijednosti (Sarajevo: Kantonalni odbor SDP BiH, 2000), pp. 40-42.

${ }^{35}$ Wachtel, Making a Nation, pp. $6 \mathrm{ff}$.
} 
simultaneously convey both national and class belonging (as for instance in the formulation 'working people') while discursively resolving possible tensions between them.

This particular blend of nationalist and communist ideas provided the broader context within which the normative views about the 'new' Yugoslav culture in the north-west of the federation were shaped. Three features of these normative framing were particularly prominent in the analyzed newspaper coverage: (a) the understanding of culture as a tool of progress and education; (b) the distinction between form and substance, coupled with an emphasis on the importance of the latter; (c) the mass character of culture. On every account, the 'new Yugoslav culture' was construed as the exact opposite of 'bourgeois' culture of the pre-war past, which allegedly also continued to flourish in the West and in the neighboring Italy.

a. Culture as an instrument of progress and education. To start with, culture was seen primarily as an instrument of progress and education rather than entertainment or leisure, and was to be aimed at the working classes. This understanding of culture came very clearly to the fore in articles aimed at mobilizing the local population for extended bouts of concentrated production known as 'shockwork' and for competitions between local factories and other organizations that were expected to boost productivity. ${ }^{36}$ Articles dedicated to shockwork and competition, typically written by local CPY leaders or left unsigned, were a common sight in the newspapers, and often appeared on the first few pages. As one such article explained, cultural activities formed an integral part of the process of ideological elevation', which would also help speed up the industrialization of the country and help construct a 'new Yugoslavia'. The article expressed concern at the lack of attention paid by

\footnotetext{
${ }^{36}$ Lilly, Power and Persuasion, pp.118-20.
} 
the local labor union organization to the cultural aspects of the competition, and called for more effort to be invested in organizing literacy classes and simulating entry into education..$^{37}$ In a similar vein, another article criticized the cultural activities accompanied the competitions organized by the labor unions for putting too much emphasis on entertainment. staging too many 'light' plays, and supplying local libraries with sentimental novels instead of promoting culture that would help recruit volunteers for shockwork and the youth labor brigades. Both leisure and entertainment were considered legitimate and necessary, yet the key task of Yugoslav cultural manifestations lay elsewhere:

they should inculcate seriousness of life needed for the construction of the new state, they should teach the people/nation [popolo] to take pride in work, to take pride in bringing one's own contribution to the creation of a common future'. ${ }^{38}$

A report intent on exposing the drawbacks of cultural and educational activities in the region was even more prescriptive, arguing that far too little effort was invested into cultural activities that would support the Yugoslav economy, and that more should be done to set up cultural events aimed at promoting participation in agricultural and other activities laid out in the five year plan. ${ }^{39}$ The emphasis on the role of culture as a tool of socialist mobilization and progress also played a key role in the selection of various fictional and semi-fictional cultural forms published in the same newspapers. For instance, the protagonists of short stories, serialized novels and comic dialogues were most often model socialist workers or peasants, involved in a revolutionary battle or in heroic re-building of their war-torn society. One such

\footnotetext{
37 'L'elevazione culturale ideologica', La Voce del Popolo, 15 January 1947, p. 1.

${ }^{38}$ N., 'Più contenuto nei programmi artistici', La Voce del Popolo, 03 Jan 1947, p. 3.

39 Štefica Kopitar: 'O nekim nedostacima u postavljanju kulturno-prosvetnog rada', Glas Istre, 03 October 1947, p. 10.
} 
serialized novel was set in the context of the October Revolution, ${ }^{40}$ while another featured Istrian peasants reminiscing about their resistance activities during World War II, and proudly talking about the freedom brought to them by the new Yugoslav rule. ${ }^{41}$

Apart from supporting specifically socialist and Yugoslav goals, cultural activities were also meant to contribute to the general cultural and civilisational 'elevation' of the Yugoslav population by developing its cultural awareness and sensibility, inculcating the habit of participating in cultural activities, and teaching them to appreciate and understand art. In an article summarizing the plan of work of the theatre in Rijeka, workers were for instance encouraged to 'treat theatre as their home', since this would purportedly 'help in their general and cultural elevation and raise the level of artistic education of the whole nation/people [narod]'. ${ }^{42}$ In a similar vein, investment into the renovation of local cultural infrastructure was presented as evidence of the government's concern for 'the raising of the cultural level of the nation/people [narod]' ${ }^{43}$ The treatment of illiteracy provides another case in point. In one article, written by the republican-level Committee for the Spreading of Literacy and most likely supplied by the Agitprop, illiteracy was presented as a major marker of cultural and civilisational underdevelopment, 'suffocating the free labor force and enthusiasm for work among our people' and hindering the progress of villages as well as the realization of the five year plan. In line with this, a report from a literacy course organized in an Istrian town insisted that illiteracy should be erased from Tito's Yugoslavia, 'since it is only in this way that we will be able to build the country and make it cultured and progressive' ${ }^{44}$ Or, as one Yugoslav citizen explained in a letter he wrote as part of his literacy training: 'The war is

\footnotetext{
${ }^{40}$ Kononov, 'Djevojka sa severa', Glas Istre, 07 November 1947, p. 6.

${ }^{41}$ Zora Pamić, 'Prve brazde', Riječki list, 03 March 1947, p. 3.

42 J.K., 'Plan rada narodnog kazališta u novoj sezoni', Riječki list, 05 September 1947, p. 3.

${ }^{43}$ Photo-news article without title, Glas Istre, 03 October 1947, p. 10.

${ }^{44}$ Zemaljski odbor za širenje pismenosti: 'Svi u borbu protiv nepismenosti!', Glas Istre, 03 October 1947, p. 10.
} 
over, but we need to continue with our struggle against illiteracy ${ }^{45}$ Literacy, in other words, was believed to constitute the very basis of Yugoslavia's cultural progress.

The notion of culture as a marker of progress served as a discursive tool for establishing a range of hierarchical distinctions within the local population, singling out those that were most in need of 'cultural elevation'. The caption accompanying the aforementioned letter, written by a model Yugoslav citizen who had just attended a literacy class, described the author of the letter as coming 'from the village', and addressing his letter at his 'comrades' at the local factory. These seemingly neutral categories, which pervaded the newspaper pages at the time, clearly indicate the hierarchical relationship between the literate 'comrades' and the hitherto illiterate 'peasant' who is now finally ready to catch up with the process of elevation an progress. The other two groups often singled as targets of the socialist civilizing project were 'women' and 'the youth'. For instance, the already discussed report from a literacy course explicitly emphasized that all the attendees were women, commended them for their effort, and argued that the newly acquired knowledge will enable them 'to raise their children as true mothers of our new society - our homeland', thus leaving no doubt as to what the primary tasks of women in the new Yugoslavia should be. ${ }^{46}$

The understanding of culture as a means of development was also used to delineate between the 'new' Yugoslav culture of the future and the 'old' culture of the pre-World War II decades. Yet in contrast to the mainstream Yugoslav discourse sketched earlier, the cultural other was not King Alexander's Yugoslavia but Italy. Aforementioned articles promoting 'cultural elevation' routinely referred to the neighboring country and the Fascist rule in particular as the party responsible for the cultural 'backwardness' of the local population. An

\footnotetext{
45 The letter was reproduced in Glas Istre, 07 March 1947, p. 5.

${ }^{46}$ Marija Banko, “Najveća nam je briga naučiti čitati i pisati”, Glas Istre, 07 March 1947, p. 5.
} 
article reporting on a cultural youth festival in Buje contrasted the flourishing cultural life of the village in the new Yugoslavia with the cultural wasteland of pre-war decades, when 'the nation/people were left without its own language, without books and education and without opportunities for cultural development' ${ }^{47}$ The same message was repeated in a report summarizing the achievements of the new administration in one of the localities in Istria, written by a prominent Slovenian member of the local Communist Party Julij Beltram:

It was not easy to take over the heritage of Fascist Italy, which was oppressing this people/nation [ljudstvo], and Croatian and Slovenian people/nation [živelj] in particular, in the most shameful manner, denationalising them and preventing any education of Slovenians and Croatians as well as the Italian working strata. It was not easy to take over and govern without personnel, since in some places as much as $60 \%$ of the population was illiterate, all thanks to a state which is boasting a cultural tradition going back two thousand years. ${ }^{48}$

This excerpt also provides a good example of the specific imbrications of communist and nationalist categories characteristic of local appropriations of Cold War discourse in this part of Yugoslavia, and is symptomatic of the challenges faced by Cold War discourse of culture in the local context. By referring to the 'Italian working strata' as one of the victims of Fascism, and mentioning them as part of the same nation/people [ljudstvo] together with 'Slovenians' and 'Croatians', Beltram is trying to sustain the perception of the communist project as a transnational endeavor that defends the interests of the working classes. Yet at the same time, his choice of categories 'Slovenians' and 'Croatians' indicates that in the case of

\footnotetext{
${ }^{47}$ T.D., 'Omladinska smotra kulture u Bujama', Glas Istre, 07 March 1947, p. 5.

48 Julij Beltram, 'Dosedanji rezultati dela ljudske oblasti v Koprščini in Bujščini', Primorski dnevnik, 03 Sept 1947, p. 1.
} 
South Slavs, communist aims coincide with the interests of the nation as a whole. Although Beltram's use of categories was not entirely at odds with the social composition of the local population - the urban, upper-class population residing in the region was indeed predominantly Italian, while the rural hinterland was overwhelmingly Slav - national and class distinctions did not coincide as neatly and were not as clear-cut as Beltram implied. Apart from neglecting the complexity of ideological, national and class identities in the region, such use of national and class based categories, similarly as other proclamations of Italo-Yugoslav brotherhood in local newspapers, also obscured the persistence of mutual suspicions and conflicts. ${ }^{49}$ Arguably, the repetitive occurrence of Fascism and Italy as the main others also helped sustain the perception of Italian culture as inherently fascist, and thereby fuelled anti-Italian prejudice in spite of official support for brotherhood.

Another element of continuity can be found in the appropriation of older cultural forms, embedded in nineteenth-century projects of nation-building and education. A good case in point is provided by the comic dialogues between Franina and Jurina, appearing on the pages of the Croatian language newspaper Glas Istre. The protagonists of these dialogues were always the same: two Istrian peasants talking in the local dialect, known from the Croatianlanguage almanacs that played an important role in Croatian nation-building in the region. One was somewhat more ignorant than the other, and provided a convenient target for mild ridicule as well as education. In each episode of the dialogue, the better-informed protagonist would talk to his friend about an important event or issue and criticize him for knowing so little about it. In all cases, the events and issues discussed were taken from the Party's agenda for that week or day, and included for instance the five year plan and the Yugoslav state budget, the building of the new railway system, and the 30th anniversary of the October

\footnotetext{
${ }^{49}$ Sabina Mihelj, 'Imperial Myths between Nationalism and Communism: Appropriations of Imperial Legacies in the North-eastern Adriatic during the Early Cold War', European Historical Quarterly 41(2), forthcoming.
} 
Revolution..$^{50}$ Although the dialogues were evidently adapted to suit the perception of culture as a tool of the communist modernizing project, they were at the same time helping solidify the perception of socialist Yugoslav nation-building as an extension of the pre-war Croatian nation-building.

b. Substance over form. Another distinct feature of debates about Yugoslav culture in this period was a pronounced aversion to 'formalism' and a strong emphasis on the ideological 'content' or 'substance' of art and culture. Yugoslav art critics were frequently warning against 'purely formal beauty', 'art for art's sake' and 'ideologically empty art', presenting them as a remnants of the 'old', 'bourgeois' culture that had the function of distracting the masses from real social problems, as well as from rational explanations and solutions to these problems. A key distinction established in such debates was the distinction between substance and form: it was the latter, argued various authors, which should be treated as decisive when evaluating a work of art. A characteristic use of this distinction appears in a commentary published on the cover page of La Voce del Popolo, written by Eros Sequi, the first secretary of the Union of Italians and one of the 'good Italians' trusted by the Yugoslav regime due to his unequivocal support for socialist Yugoslavia. ${ }^{51}$ In his view, people should be prepared to compromise on the 'external aspects' of culture, and keep in mind that 'external beauty can only be established once one has assured a progressive substance' ${ }^{52}$

The distinction between substance and form was repeatedly drawn upon in articles about various cultural activities in the region. A report on the cultural youth festival organized in the Istrian town of Buje commended the participants for staging 'good plays', and as evident

\footnotetext{
50 'Franina i Jurina', Glas Istre, 03 April 1947, p. 7, 07 March 1947, p. 7, and 07 November 1947, p. 7, respectively.

${ }^{51}$ Ballinger, History in Exile, p. 213.

${ }^{52}$ Eros Sequi, 'Per la nuova cultura', La Voce del Popolo, 01 January 1947, p. 1.
} 
from the titles listed, a prime criterion was the inclusion of socialist ideas or motives from the Yugoslav partisan struggle during World War Two. One such play, entitled The Hotel of the Past, was praised for revealing 'the deception, exploitation and inhospitality in hotels of the past', and implicitly suggesting that the Yugoslav hotels of the future will be fairer to both their employees and guests. ${ }^{53}$ Following similar criteria, a review of cultural events organized by the local labor unions disappointedly commented on the 'ideological emptiness' of some of the events, and listed several theatre plays that would have allegedly better served the purpose of education and mobilization. ${ }^{54}$

The contrast between ideological emptiness and progressive substance was also used to demarcate the 'new' Yugoslav culture in spatial, geo-cultural terms. The exemplary models of cultural products and activities that paid due attention to 'substance' were often found in the Soviet Union, while negative examples of 'formalistic' culture were associated with 'the West'. In an article about Soviet culture translated from the Soviet daily Pravda, Western culture and civilization were described as 'superficial', hiding a 'spiritual poverty of contemporary imperialists and their followers'. In contrast, Soviet culture allegedly 'arose from and blossoms on the basis of a genuine democracy, brotherly friendship of equal nations', and now 'provides the rallying point for all the progressive forces of the world' ${ }^{55}$ Differences between Yugoslav and Italian culture were scrutinized through the same normative lens. The article written by Eros Sequi is very revealing in this respect. In his view, Italians, including those living in Yugoslavia, were particularly prone to the 'bourgeois' and overly 'formalistic' treatment of art and culture, since their cultural capabilities were 'most ruthlessly manipulated and made deviant by decades of Fascism'. ${ }^{56}$ This 'deviant' culture was

\footnotetext{
53 T.D., 'Omladinska smotra kulture'.

${ }^{54}$ N., 'Più contenuto'.

55 'Svjetski značaj sovjetske kulture', Riječki list, 05 September 1947, p. 3.

${ }^{56}$ Sequi, 'Per la nuova cultura', p. 1.
} 
seen not only as an element of 'the old society' dominating in Italy, but also as 'the secret weapon of imperialism' operating from within the socialist Yugoslav state itself, and hampering its progress. In contrast, inhabitants of Slavic descent were considered to be 'much more open to re-education', since their sensibilities have not been contaminated by fascist education. ${ }^{57}$ It was probably not a coincidence that such a condemnation of Italian culture came from the secretary of the Union of Italians. This helped avoid the charge of antiItalian prejudice, and solidified the difference between 'good' and 'bad' Italians.

c. Culture as a mass phenomenon. The third notable feature of the framing of culture in this period was the emphasis on its mass character. The new Yugoslav culture was expected to extend its appeal well beyond the educated elites and thereby contribute to the erasure of class boundaries. Yugoslavia was to be a country in which culture addressed the genuine needs of the 'working people', in which the qualitative distinction between elite and mass culture was abolished, and in which high-quality culture was produced and enjoyed at a mass scale. An article written by a Croatian language teacher who worked as an editor and journalist for various newspapers published in the region ${ }^{58}$ proudly announced that Yugoslavia was 'a country of new culture, in which a book is not a good produced for the market, but [...] an integral part of working people/nation's [radnog naroda] life'. ${ }^{59}$ An article detailing the work plan of the theatre in Rijeka was marked by the same normative assumptions about the role of culture, emphasizing the theatre's efforts to 'massify the theatre' and 'turn the whole people/nation [narod] into a theatre audience' by introducing season tickets for labor union members. ${ }^{60}$

\footnotetext{
${ }^{57}$ Ibid., p. 1.

${ }^{58}$ Vladimir Kadum, 'Tone Peruško - životopis', Methodological Horizons, Vol. 4, No. 7-8, pp. 9-11 (2009).

${ }^{59}$ Tone Peruško, 'Nagradjena knjiga o Rijeci', Riječki list, 02 March 1947, p. 3.

${ }^{60}$ J.K., 'Plan rada narodnog kazališta'.
} 
Not all of the cultural products and activities at the time, however, were equally successful at attracting mass participation, and much of the reporting was dedicated to criticizing particular events and activities for failing to live up to the new cultural ideals. For example, an article evaluating the cultural-educational activities in the city of Rijeka and its surroundings criticized the organizers for their failure to establish strong ties with mass organizations and achieve greater popular appeal. ${ }^{61}$ Apart from that, mass appeal also played a key role in distinguishing it from Italian and more broadly 'Western' culture, as well as from the culture of Fascist Italy. While the articles acknowledged that Italian culture is highly developed, they were also pointing out that the ability to appreciate and enjoy it was limited to the wealthy, educated elites rather than being democratically available to its whole population, including the working classes. The aforementioned article discussing the work plan of the Rijeka theatre contrasted the strategies for massification adopted by the theatre with the situation under Italian rule, when the authorities 'calculatedly diverted the working people from theatre, deliberately entertaining them with light comedies [...] in order to distract them from political and social problems'. ${ }^{62}$ In contrast, the Soviet Union was presented as a shining example of the growing 'massification' (omasovljenje) of culture, exemplified in the mushrooming of cultural institutions and activities that made culture available to the masses. In an article translated from Pravda, depicting the cultural and educational achievements of the Soviet Union since the revolution, provided details about the number of new theatres and schools built and books issued since the revolution, and boasted about the rising educational level of the general population. ${ }^{63}$ A similar quantitative approach to measuring cultural development was employed when measuring the cultural progress of Yugoslavia. Occasionally, newspapers published lists with exact numbers of books issued, new magazines and newspapers established, or libraries built since the formation of the 'new' Yugoslavia.

\footnotetext{
${ }^{61}$ Kopitar, 'O nekim nedostacima ...'.

${ }^{62}$ J.K., 'Plan rada narodnog kazališta ...', p. 3.

${ }^{63}$ Kaftanov, '30 godina ...', p. 8.
} 
On the whole, journalistic discourse about culture in 1947 clearly contributed to the discursive politics of Yugoslav socialist identity. The prevailing normative distinctions were used to assess the value of local cultural production and differentiate between more and less valuable examples of cultural events and activities, and more or less 'developed' segments of the population, as well as served to delineate the position of Yugoslav culture in both geopolitical and historical terms, contrasting it with the 'old' culture of the pre-revolutionary past, as well as with the culture of its contemporary others in the West. Local journalists also appropriated these normative ideals to suit the local power struggles and the associated, historically constituted categories and distinctions. In this sense, discourses about culture served to delineate the achievements of new Yugoslav culture in relation to the Fascist past, as well as in relation to contemporary Italian culture. Negotiating the relationship with the Italian minority and its culture proved particularly tricky, and reveals the challenges encountered by Yugoslav discourses about culture in the northwest of the federation. Caught between the ideals of trans-national brotherhood of the working classes on the one hand, and the need to construct a Fascist enemy on the other hand, journalistic discourses about culture did little to dispel mutual suspicions, despite declaratively promoting the ideals of ItaloYugoslav brotherhood. In practice, the break with the 'old' culture, inter-ethnic suspicions, and the sedimented forms of knowing and classifying identity and difference was far more difficult to achieve than journalistic discourse would have us believe.

Apart from obscuring continuities with the past, the clear-cut distinctions drawn by media discourse about Yugoslav culture also neglected structural similarities in cultural practices and values on both sides of the Iron Curtain. There is of course no doubt that the notions of culture charted above have a lot in common with the Soviet system of cultural values, as 
established in the post-revolutionary period, ${ }^{64}$ as well as with debates about culture elsewhere in the Eastern bloc in the post-1945 period.$^{65}$ Yet while acknowledging that the ideas about the desirable content of culture in the East and West differed, we should also keep in mind that being able to provide culture for the masses was a goal pursued by intellectuals on both sides of Cold War divide. ${ }^{66}$ Modern means of mass communication were believed to provide particularly powerful instruments of cultural development and modernization. For many American social scientists and UNESCO officials at the time, the media were 'great multipliers', capable of increasing the amount of information people can send and receive, and thereby speeding up processes of change in even the most remote backwaters of the world. ${ }^{67}$ The habit of assessing development by means of quantitatively measuring the proliferation of mass culture was also not unique to the Eastern block. Literacy rates, newspaper circulation and radio receivers per capita were all indicators widely adopted in post-war American studies of modernization and development. ${ }^{68}$ Given the shared history of 'culture counting' - a practice that became widespread across Europe by the mid-nineteenth century $^{69}$ - this structural similarity is hardly surprising, and is one of the features that attest to the shared roots of the understanding of culture on both sides of the Cold War divide.

Another shared feature, prominent especially in the early post-war years, was the disdain for genuinely popular cultural forms. Despite the constant promotion of culture and art inspired by the needs of 'the working masses', Yugoslav commentators were dismissive of cultural

\footnotetext{
${ }^{64}$ Fitzpatrick, The Cultural Front, 217-219, Hoffmann, Stalinist Values, pp. 15-56.

${ }^{65}$ Caute, The Dancer Defects, pp. 284-285, 380-382, 420-422.

${ }^{66}$ Cf. Andrew Ross, 'Containing Culture in the Cold War', Cultural Studies, Vol. 1, No. 3, pp. 328-348 (1987).

${ }^{67}$ E.g. Daniel Lerner, The Passing of Traditional Society: Modernizing the Middle East (New York: Free Press, 1958), Lucian W. Pye, The Concept of Political Development, Annals of the American Academy of Political and Social Science, Vol. 358, No. 1, pp. 1-13 (1965).

${ }^{68}$ E.g. Karl W. Deutsch, 'Social mobilization and political development', The American Political Science Review, Vol. 55, No. 3, pp. 493-514 (1961), Everett M Rogers, Mass Media Exposure and Modernization among Columbian Peasants, Public Opinion Quarterly, Vol. 29, pp. 614-625 (1965).

${ }^{69}$ David Vincent, The Rise of Mass Literacy: Reading and Writing in Modern Europe (Cambridge: Polity Press, 2000), pp. 4-5.
} 
forms actually enjoyed by the same 'masses'. Jazz and modern dance, they argued, will instill idleness and promote worldly pleasures instead of mobilizing the population for the construction of socialism. Ironically, in a country that prided itself on being genuinely popular, owned and ruled by 'the people', popular cultural preferences did not seem to matter. In one article, jazz was described as 'hysterical', ${ }^{70}$ while another described 'boogiewoogie' as a phenomenon that clearly 'has nothing to do with culture'. ${ }^{71}$ These anxieties were shared by Soviet Party officials, who were constantly concerned about the vulnerability of the Russian people to various cultural seductions and deviations orchestrated by the capitalist world. ${ }^{72}$ Similarly as the inclination to associate the proliferation of mass culture with development and progress, such fears were far from being specific to the Eastern block. The popularity of American movies, music, and dances among young East and West Germans in the early 1950s provoked strikingly similar responses in both Germanies, causing anxiety over the oversexualization of women and feminization of men purportedly stimulated by these cultural forms. ${ }^{73}$ Feeding on pre-existing cultural fears of mass society, consumerism and modernity, such anxieties constituted another key thread shared by early Cold War cultural policies and discourses about culture in both the East and the West.

By obscuring these fundamental similarities and continuities, the early Cold War discourse about Yugoslav culture in the region helped sustain the belief in the uniqueness and superiority of the socialist system vis-à-vis the political, economic and cultural structures of the past, as well as those implemented in the West, and thereby helped prevent systematic comparisons that could have challenged the legitimacy of the Yugoslav regime at the time.

\footnotetext{
${ }^{70}$ Sequi, 'Per la nuova cultura', p. 1.

71 'Gledaliških dvoran za SNG ni, fašistom pa so vedno na razpolago' Primorski dnevnik, 03 Dec 1947, p. 2.

${ }^{72}$ Caute, The Dancer Defects, p. 7.

${ }^{73}$ Poiger, Jazz, Rock, and Rebels, pp. 31-70.
} 


\section{Cultivating the nation and entertaining the masses}

After Yugoslavia's expulsion from the Cominform in 1948, Yugoslav cultural policies and public discourses about culture started departing from the patterns we have observed in the previous section. This shift formed an integral part of more wide-ranging changes which eventually let to the rejection of 'Soviet' or 'Stalinist' models and gave rise to a new 'founding myth' of socialist Yugoslavia, namely 'worker's self-management' ${ }^{74}$ One of the key deficiencies of the Stalinist system, as identified by the CPY leadership, lied in the highly centralized Party-State apparatus, which obstructed the implementation of 'direct social selfmanagement' ${ }^{75}$ As stated in the 1952 Resolution and Statue adopted at the Sixth Congress of the CPY - renamed at that point into the League of Communists of Yugoslavia (LCY) - the Party should not act as 'the direct operative manager and commander in economic, State, and social life', but rather focus on the 'political and ideological work in educating the masses' ${ }^{76}$ Changes taking place in the realm of cultural policies followed a similar logic. Already in 1949, the CPY leadership came to the conclusion that the old cultural policies, aimed at changing popular consciousness with the help of 'administrative means', were misguided. Instead, they argued for a less intrusive and prescriptive approach to culture, and for greater ideological pluralism. ${ }^{77}$

In the aftermath of these shifts within political leadership, new tropes entered the Yugoslav public discourse, organized around slogans such as 'debureaucratization', 'decentralization', and of course 'workers' self-management' ${ }^{78}$ Journalistic attacks on 'Western' and 'idealist'

\footnotetext{
${ }^{74}$ Dennison Rusinow, The Yugoslav Experiment, 1948-1974 (London: C. Hurst \& Company, 1977), p. 61.

${ }^{75}$ Ibid., p. 55.

${ }^{76}$ Quoted in ibid., p. 75.

${ }_{77}^{77}$ Marković, Beograd između istoka i zapada, pp. 325-7.

${ }^{78}$ Rusinow, The Yugoslav Experiment, p. 52.
} 
art were becoming less frequent, socialist realism was no longer hailed as the aesthetic deal, ${ }^{79}$ and newspapers were increasingly filled with critical reports about repression in the Soviet Union, as well as with information drawn from Western sources. ${ }^{80}$ These shifting discourses crystallized around a new understanding of Yugoslav identity and culture, based on the idea of Yugoslavia as a meeting point of the East and the West, but belonging to neither. 'We,' argued Tito in a speech delivered in 1954, 'are following our own path into socialism, and we will not allow anyone, neither those in the East nor those in the West, to make us stray away from this path ${ }^{81}$ Similar ideas were being voiced by some of the most prominent members of the Yugoslav cultural elites at the time, including Miroslav Krleža, who insisted on the uniqueness of Yugoslav culture, and its distinctiveness both in the relation to the East and to the West. ${ }^{82}$ This new geo-political identity provided the overarching cultural theme for a range of cultural policies aimed at creating an overarching Yugoslav culture until the early $1960 \mathrm{~s},{ }^{83}$ but was then overshadowed by the rise of particular national identities - an issue we return to later.

Whether and to what extent Yugoslavia actually managed to fulfill the promises of its distinct road to socialism remains disputed. While the LCY did indeed gave up its monopoly over the political decision-making process, it retained control over the appointment of key personnel in the People's Front - renamed in 1953 into the Socialist Alliance of the Working People (SAWP) - as well as in the trade unions, municipal governments and other organizations. ${ }^{84}$ In the realm of economic policy, the state retained a powerful role, and although the successive waves of economic reforms did indeed bring significant changes that helped increase the

\footnotetext{
${ }^{79}$ Marković, Beograd između istoka i zapada, p. 394.

${ }^{80}$ Novak, Hrvatsko novinarstvo, p. 450.

${ }^{81}$ Primorske novice, 02/04/1954, 1.

${ }^{82}$ Marković, Beograd između istoka i zapada, pp. 395, 505.

${ }^{83}$ Wachtel, Making a Nation, pp. 128-72.

${ }^{84}$ Rusinow, The Yugoslav Experiment, pp. 73-4.
} 
general well-being of Yugoslav citizens, the Yugoslav system effectively remained socialist in nature, and self-management was never fully implemented in practice. ${ }^{85}$ Changes in the realm of culture were possibly more far-reaching. The Departments of Agitprop and Propaganda were formally abolished in 1952, and Yugoslavia's cinemas, news stands, concert halls and bookshops opened their doors to cultural imports from the West. Between 1945 and 1950, Yugoslavia imported a total of 240 films, of which 192 were produced in the Soviet Union. After 1950, the Yugoslav film market was dominated by film imports from the West, above all from the USA, but also from France, Italy and Britain. ${ }^{86}$ The early 1950s also saw the return of comics; in 1952, the daily newspaper Politika, sponsored by the SAWP, started publishing Donald Duck comics, and re-launched its popular weekly comic magazine.$^{87}$ At the same time, official attitudes towards jazz and popular music softened as well, though a measure of suspicion remained.$^{88}$ Nevertheless, periodic purges, closing down of journals and persecutions served as constant reminders that cultural experimentation has its limits.

Influenced by broader changes in the realm of culture, politics and economy, the Yugoslav media system also started undergoing a significant transformation, although major changes took place only in the 1960. This was a period when liberal-minded party leaders were gaining ground across Yugoslavia, and were pushing for further market reforms modeled on the West and for greater intellectual and religious freedoms. ${ }^{89}$ The principles of selfmanagement were finally being translated into legislative changes that allowed the media to elect their top management, which increased their organizational independence and

\footnotetext{
${ }^{85}$ Milica Uvalić, Investment and Property Rights in Yugoslavia: The Long Transition to a Market Economy (Cambridge: Cambridge University Press, 1992).

${ }^{86}$ Marković, Beograd između istoka i zapada, pp. 445-6.

${ }^{87}$ Ibid., pp. 447-9.

${ }^{88}$ Luković, Bolja prošlost, pp. 10-20.

${ }^{89}$ John Lampe, Yugoslavia as History: Twice There Was a Country (Cambridge: Cambridge University Press, 2000), pp. 284-199,
} 
contributed to the professionalization of media management. ${ }^{90}$ Yugoslav journalists achieved greater political independence as well, reformed their professional organization, and redefined its key aims by drawing on Karl Popper's concept of the open society. ${ }^{91}$ At the same time, as a result of economic reforms, financial independence of publishing houses and broadcasting organizations increased as well: direct state funding decreased sharply, taxation levels were dropped, broadcasting organizations were allowed to set subscription fees based on service costs, and acquired control over $70 \%$ of their total profits. Advertising revenues began constituting an increasingly significant proportion of revenue, even in the broadcasting sector..$^{92}$ The financial independence of publishing houses and broadcasting organizations increased as well, and so did the incentives to maximize profits, for instance by opening the pages of daily newspapers to entertainment and by publishing special interest weekly magazines dedicated to sports, fashion, television and film and the like. Circulation numbers from the period speak for themselves: while the total circulation of newspapers - in part affected also by the rising popularity of radio and television - decreased from 10.06 millions in 1964 to 8.67 in 1970 , the total circulation of magazines increased from 3.8 million to 8.24 million in the same period..$^{93}$

The 1960s were also marked by a strengthening of nationalist antagonisms in the federation. The combination of economic reforms and a more open climate allowed for the consolidation of key nation-building institutions, associated with the constituent Yugoslav nations. It did not take long for these developments to prompt a revival of nationalist antagonisms, regional economic rivalries, and mutual suspicions between national majorities and minorities. ${ }^{94}$ In the public realm, grievances were more and more often expressed in ethnic terms, a tendency

\footnotetext{
${ }^{90}$ Robinson, Tito's Maverick Media, pp. 44-5.

${ }^{91}$ Novak, Hrvatsko novinarstvo, pp. 606-609.

${ }^{92}$ Robinson, Tito's Maverick Media, p. 44.

${ }^{93}$ Ibid., p. 46.

${ }^{94}$ Lampe, Yugoslavia as History, pp. 304-309.
} 
facilitated by the decentralization of the media system in this period. ${ }^{95}$ Subjected to republican rather than federal control, the separate republican media systems were increasingly functioning as proto-national media systems, aimed at first at the different national 'imagined communities', ${ }^{96}$ and only then at the wider Yugoslav community. Cultural policies aimed at creating an integrated Yugoslav culture were abandoned, heated exchanges over 'unitarism' were becoming more and more common, and were paralleled by the rising prominence of nationalist ideas in educational and linguistic policies, and increasing divergence of the history and literary curricula taught in each of the republics. ${ }^{97}$ Ultimately, the alliance between liberal reformers and nationalist leaders proved deadly for both. By the end of 1971, it was clear that federal authorities were gearing up for a thorough purge of both liberals and nationalists from all major political and cultural institutions, and by the end of 1972, virtually all the leaders of liberal reforms that marked the late 1960s have disappeared from public light.

These developments inevitably had an impact on the Yugoslav press examined in this paper, both in terms of its institutional arrangements as well as with regard to its form and content. Most newspapers have adopted a new (smaller) format, and introduced several new rubrics aimed primarily at attracting additional readers. Novi list (previously entitled Riječki list) and Glas Istre introduced an equivalent of the 'Page Three Girl' on their back pages, and Primorski Dnevnik took every opportunity to include a photo of a half-naked popular singer or actress, making the visual layout of these newspapers strikingly different from the one characteristic of the late 1940s (Figures 1 and 2). Advertising, virtually nonexistent in 1947,

\footnotetext{
${ }^{95}$ Robinson, Tito's Maverick Media, pp. 193-4.

${ }^{96} \mathrm{Cf}$. Benedict Anderson, Imagined Communities: Reflections on the Origins and Spread of Nationalism, 2nd edn (London: Verso, 1991).

${ }^{97}$ Wachtel, Making a Nation, pp. 173-97.
} 
was now a regular feature, and included half-page adverts for Coca-Cola and several adverts for various shops in the nearby Italian towns and cities. ${ }^{98}$

[Figures 1 and 2 about here; suggested size and layout: about 1/4 of page each, printed side by side.]

Figure 1: Cover page of first issue of Rijećki list, 01 March 1947.

Figure 2: Back page of Novi list, 01 April 1971.

In parallel with these shifts, the understanding of culture was changing as well. The investigation is limited to the coverage published in 1971, a point when many of the key trends just discussed in relation to the $1960 \mathrm{~s}$ - in particular the growth of nationalism and the prominence of entertainment in the media - reached one of their peaks. The framing of culture in this period was marked by both of these trends, and was, quite unsurprisingly, characterized by a far greater diversity of views on the social functions, form and content of culture. While some of the ideas promoted in the 1947 remained present, they now coexisted alongside other, sometimes radically different views. The most prominent new elements of the framing of culture included the following: (a) culture as an instrument of national integration and preservation; (b) a greater emphasis on the quality of artistic form rather than content; and (c) attempts to find a 'third way' between education and entertainment, commercialization and elitism.

a. Culture as an instrument of national integration and preservation. Although culture was still considered to have an important social and political role, this role was no longer linked primarily to the needs of the working classes, but above all to the interests of the individual

\footnotetext{
${ }^{98}$ E.g. Novi list, 18 September 1971, p. 27; Novi list, 01 March 1971, p. 11.
} 
Yugoslav nations. Culture was seen as an organic entity tied to the national body, destined to serve as an instrument of both national integration and national preservation. Reviews of cultural events were frequently suffused with organicist metaphors known from nineteenthcentury national romanticism. An article published in the Croatian language daily Novi list thus described Croatian poetry as 'an organic, indivisible whole', which encompasses 'everything that was ever written in Croatian language from the first known beginnings of poetry to today'. ${ }^{99}$ Another article insisted that local radio stations should broadcast traditional music from various Croatian regions, and argued that this will lead 'to an even tighter integration into a unified entity'. ${ }^{100}$ Reports and commentaries found in Slovenianlanguage newspapers were no different in this respect. One report, written by a commentator specializing in music, referred to a well-known Slovenian coir as 'the voice of the nation and its pride', and described its singing as 'growing from the nation and for the nation'.101 Another article, written by a prominent Slovenian art historian, argued that art is 'the deepest companion of the life of every nation, and therefore carries in it the image of this nation' ${ }^{102}$

In contrast to the early post-war years, when nationalist framings of culture remained intertwined with ideas of pan-Yugoslav patriotism and notions of international class struggle, compatibility with these ideas were now of marginal importance; what mattered more was the contribution art and culture could make to national survival and integration. The emphasis on national survival and integration, along with the ubiquitous presence of organic metaphors exemplified also in the afore-examined excerpts - 'growth', 'organic, indivisible whole' also signaled a subtle semantic shift in the notion of culture itself, and in the associated

\footnotetext{
${ }^{99}$ D. Pavešić: 'Zlato hrvatskog pesništva', Novi List, 14 April 1971, p. 14.

${ }^{100}$ Bogdan Potkonjak, 'Kakav RTV centar u Rijeci', Novi list, 01 May 1971, p. 8.

${ }_{101}^{10}$ Marijan Zlobec, 'Na Krasu bo gostoval APZ Tone Tomšič', Primorske novice, 26 November 1971, p. 7.

102 Lojze Bizjak, 'Bit resničnosti v umetnosti', Primorske novice, 05 November 1971, p. 8.
} 
understanding of its social and political role, which now centered on preservation rather than change.

The exception to this rule was the framing of culture in the Italian minority newspaper. $L a$ Voce was not only devoid of openly nationalist descriptions of Italian culture, but even included articles that were unequivocally critical of the rise of nationalist sentiments. Such was the case with an article written by Andrea Benussi, then president of the Union of Italians and known for his unequivocal support of the Yugoslav socialist cause, ${ }^{103}$ who condemned nationalist tendencies and explicitly called for a 'purification' of party ranks to restore unity. ${ }^{104}$ When defending the cultural rights of the minority, La Voce was careful to frame its demands in accordance with the discourse of Yugoslav 'brotherhood and unity' and the rhetoric of revolutionary internationalism in much the same way as all of the newspapers in the region did in 1947. For instance, one characteristic article warned that the rise of Croatian nationalism in the region was running the risk of wasting 'the rich patrimony of the class struggle among the proletarians of Istria'. ${ }^{105}$

Such attitudes of La Voce can in part be explained as a defensive reaction to the rise of Slovenian and especially Croatian nationalism in the region. However, they also bear the imprint of a well-established post-1945 identity narrative that emphasized the contribution of Italians to the partisan struggle and their commitment to multiethnic coexistence. This narrative was coined in response to the post-war perception of the Italian minority as a potentially threatening 'fifth column', and served to promote an image of Italians as loyal citizens of socialist Yugoslavia. ${ }^{106}$ While public expressions of Slovenian and Croatian

\footnotetext{
${ }^{103}$ Ballinger, History in Exile, pp. 124-5.

${ }^{104}$ Andrea Benussi, 'Ripulire il Partito', La Voce del Popolo, 16 May 1971, p. 2.

105 'Appoggiare tutte le iniziative di seria ricerca storica', La Voce del Popolo, 14 March 1971, p. 5.

${ }^{106}$ Ballinger, History in Exile, pp. 212-15.
} 
nationalism were on the rise, $L a$ Voce chose to rely on its tested and proven legitimating narrative, and continued to emphasize its loyalty to socialism. Much as in 1947, discourses about culture served to delineate between the South Slavs and the Italian minority in the region, yet the logic was now strangely reversed: the Italian minority, considered a potential traitor in 1947, emerged as the stronghold of socialist Yugoslav values.

In summary, the notion of culture as a means of national preservation still served somewhat similar discursive ends as the understanding of culture as a tool of progress did in 1947 namely, it was used to define 'our' culture from within, and distinguish between what was good and bad. Yet in contrast to 1947, 'our' culture was now most often limited to individual national cultures - Slovenian, Croatian, Italian - rather than being explicitly equated with Yugoslav culture at large, let alone working class culture. Furthermore, the idea of culture as a means of national preservation was rarely used to explicitly position 'our' culture in geopolitical and historical terms. References to the Fascist past and the partisan struggle, and even to the post-war 'Stalinist' period, were few and far apart. Instead of emphasizing the revolutionary break and progress, reporting about culture was now more concerned with cultural preservation. Arguably, such discursive framing of culture had the exact opposite effect of the 1947 framing: if the 1947 emphasis on the revolutionary break and progress had the effect of obscuring historical continuities, the 1971 emphasis on preservation masked important changes, in particular the growth of nationalist sentiments and the decline of Yugoslav unity. To put it differently, journalistic discourse was constitutive of the rise of nationalist antagonisms, yet presented national differences as something that was already an attribute of reality, thereby obscuring its own role in shaping this same reality. 
b. Form over substance? Another feature of the framing of culture apparent in 1971 was the emphasis on artistic skills and the technical execution of cultural events. Although articles critical of 'modern' and abstract art, as well as those calling for more socially engaged art, continued to appear, a substantial proportion of cultural reviews now paid attention to issues such as the quality of vocal delivery or the pictorial qualities of a work of art, without necessarily linking these to questions of ideological substance or mobilizational potential. For instance, a review of a local art exhibition, written by the Trieste-born avant-garde artist Milko Bambič, ${ }^{107}$ focused on the choice of techniques and on the emotional and aesthetic effects the paintings had on the audience. ${ }^{108}$ Even in articles discussing the institutional organization of cultural activities and the various reforms needed in the sector, attention was paid primarily to questions of efficiency and allocation of resources, without mentioning any specific ideological issues. ${ }^{109}$ Also notable was the increase in the proportion of articles limited primarily to reporting rather than critique and evaluation.

Occasionally, even the whole idea of culture as an inherently political activity - an idea that permeated much of the reporting in the late 1940s - was being put under question. This argument was particularly prominent in a lengthy commentary written by the Croatian writer and literary critic Igor Mandić, published in response to the blacklisting of a popular Croatian singer Vice Vukov on Radio Sarajevo, presumably because the audience found his songs to be too nationalistic. Mandić, who was known for his provocative writings, argued that popular singers should not be judged on the grounds of their political views. Rather, the audience should focus exclusively on their qualities as performers: 'singers of popular music should be kept where they belong, that is, behind a microphone and in front of an orchestra,

\footnotetext{
${ }^{107}$ Marko Vuk and Valentina Verani, Milko Bambič, 1905-1991: Življenje in delo (Nova Gorica: Goriški muzej, 1992).

${ }^{108}$ Milko Bambič, 'Demetrij Cej razstavlja v tržaški knjigarni', Primorski dnevnik, 18 September 1971, p. 4.

${ }^{109}$ E.g. Z. L., 'Še vedno razprave o kulturi', Primorske novice, 05 March 1971, pp. 1 and 12; N. G., 'Po katerih tirih bo šla kultura', Primorske novice, 10 December 1971, p. 4.
} 
and not on a political stage'. ${ }^{110}$ In a curious twist of argument, the idea of popular culture as apolitical was used to defend a singer whose work had unambiguous political repercussions.

The normative expectations about form and content outlined here rarely served to explicitly position 'our' culture in geopolitical and historical terms, and were instead, just as the notion of culture as a means of national preservation, used primarily to delineate the internal hierarchies of 'our' culture. It is also important to note that the multitude of normative views about the relative importance of form and content in judging culture was evidently underpinned by fundamental disagreements, which constitute yet another aspect that makes the 1971 journalistic discourse about culture very different from the discourse in 1947. Later in the same year, this ambiguity was at least temporary reduced by means of political purges. Among other things, Vice Vukov was branded a Croatian nationalist and remained abroad for several years due to fear of persecution, while Mandić was barred from publishing for a whole decade. These developments suggest that the attempt to divorce culture from politics had its limits - it was acceptable as long as the culture in question was not in any direct way challenging the legitimacy of Yugoslav 'brotherhood and unity'.

c. Between entertainment and education, between 'trash culture' and elitism. The disdain for popular culture and the emphasis on culture as a means of ideological elevation were far less prominent in 1971 than they were in 1947. Instead, reporters were now accepting the existence of differences between elite and popular cultural tastes as a given and relatively rarely linked culture specifically to workers. The range of cultural forms discussed and incorporated into newspapers itself attests to this change of attitudes. Serialized novels written in the tradition of socialist realism were now nowhere to be found, and were most

\footnotetext{
${ }^{110}$ Igor Mandić, 'Embargo na Vukova', Novi list, 18 September 1971, p. 5.
} 
often replaced by detective stories and sentimental novels. ${ }^{111}$ The festival of jazz organized in Ljubljana received lengthy coverage and was described as a cultural event with 'a rich program' and 'an established reputation'. ${ }^{112}$ News about American, but also Italian, French and English films and music, often accompanied by glamorous photos of famous actors and singers, were appearing on a regular basis, and often received sympathetic coverage. ${ }^{113}$ Newspapers were full of admiration for popular songs, concerts and festivals that would earlier be dismissed as worthless and excessively idealistic, including foreign spectacles such as the Sanremo Music Festival. ${ }^{114}$ The domestic popular music industry had taken root as well, and reports attested to the great popularity of Yugoslav groups and singers, including for instance the Croatian singer Ivo Robič, both at home and abroad. ${ }^{115}$ To be sure, in 1971, none of this can be considered new. The proliferation of popular entertainment was a notable trend already in the 1950s and provoked concern among the members of the LCY and the SAWP ever since. Yet as explained earlier, this trend became far more pronounced in the 1960s and the early 1970s.

Not everyone, of course, was equally enthusiastic about the proliferation of entertainment culture in Yugoslavia. The tabloid-style coverage of (mostly Western) popular culture was itself conveying a rather mixed message: articles about celebrities were frequently interspersed with stories about unhappy private lives, hints to links with criminal or immoral activity, or simply plain weirdness. Most importantly, the Western pop icons were all presented as unmistakably foreign: as attention-grabbing and entertaining pieces in the

\footnotetext{
111 For example, Novi list published a cartoon strip version of Emile Richebourg's La Petit Mionne, a sentimental historical novel originally published in France in nineteenth century.

112 '12. mednarodni festival jazza', Primorski Dnevnik, 01 June 1971, p. 4.

${ }^{113}$ E.g. S. R., 'Življenje Marilyn Monroe', Primorski Dnevnik, 01 June 1971, p. 4.

${ }^{114}$ E.g. K. B., 'È stato il festival di Lucio Dalla', La Voce del Popolo, 01 March 1971, p. 3.

${ }^{115}$ E.g. 'Ivo Robić all' “Eden” di Rovigo', La Voce del Popolo, 14 April 1971, p. 9.
} 
mosaic of the "colorful world'116 that was not really our own. As a true object of desire, Western popular culture remained simultaneously fascinating and threatening, and therefore best kept at an arms length: as something to marvel at and enjoy, but never accept as one's own. Also worth noting is that the symbolic map of the world charted by the newspaper coverage of popular culture in north-western Yugoslavia was oriented almost exclusively to the West, while the rest of the world virtually disappeared from sight. Although imperfect and in some ways threatening, the West represented the main object of interest.

The more high-brow segments of press coverage of culture were sending a more unambiguous message about the perils associated with Western popular imports, and popular culture in general. The dangers of 'commercialization' and 'consumerism' were periodically debated among members of the LCY and the various SAWP organs in Croatia at the time, ${ }^{117}$ and were also among the key issues discussed at a conference of the Association of CulturalEducational Organizations of Slovenia organized in 1971. ${ }^{118}$ 'Trash culture' (̌̌und) - a derogative term that encompassed everything from detective and sentimental novels to popular music and comics - was particularly often singled out as the target. In an article announcing an imminent concert by a major Slovenian coir, the commentator described the choir's singing as 'growing from and for the nation', praised it for expressing an awareness of 'one's self [and] of human ties', and contrasted it with the 'consumerist nonsense' of šund. ${ }^{119}$ As this comment indicates, negative attitudes towards popular culture were not necessarily based on the idea that such culture was ideologically hostile to the socialist system, but rather

\footnotetext{
116 'Colorful Globe' (Šareni globus) was the title of a rubric in Novi list which typically contained tabloid-style short stories from around the world, most of them dedicated to Western actors and singers.

${ }^{117}$ Senjković, Izgubljeno u prijenosu, pp. 47-89.

118 'Kulturna politika in potrošniška kultura', Primorski dnevnik, 03 October 1971, p. 6.

${ }^{119}$ Zlobec, 'Na Krasu bo gostoval ..., , p. 7.
} 
on the conviction that it was somehow devoid of meaning, and thus of too low quality. ${ }^{120}$ This was in tune with views held by some of the leading LCY members; as Josip Broz Tito explained in one of his speeches delivered in the early 1960s, šund was not to be considered as an expression of Western culture, but as something the West itself considers negative. ${ }^{121}$

While voicing criticisms of popular culture, many commentators were nevertheless eager to demarcate their criticisms from what they saw as unacceptable elitism. Some of the representatives of Slovenian cultural organizations discussing the threats of consumerism were at the same time warning of the danger of 'deviating into an elitist understanding of culture'. In a socialist society, they claimed, there is simply no place for elite culture. ${ }^{122}$ In other words, popular culture was seen simultaneously as a threat and a blessing: a threat to established cultural canons, yet at the same time also a welcome shield against the dangers of elitism. As an article about fashion explained, the rise of mass produced, cheap clothing had the capacity to make designer items more easily available to an average consumer, yet on the other hand, it could lead to uniformity and stimulate the consumption of items one does not really need. Instead of siding either with designer fashion or with mass produced clothing, the article leaves the choice to the consumer, who should be perfectly able to avoid both extremes and find an individual path between the two. ${ }^{123}$ Similar 'balancing acts' could be found in articles about other forms of culture. As the director of a regional chain of cinemas explained in an interview, the key to the rising number of cinema-goers lied in finding a middle way between the demands of the 'intellectuals' and the cultural preferences of the

\footnotetext{
${ }^{120}$ Similar views were apparent also in debates among intellectuals and cultural policy makers at the time. See Senjković, Izgubljeno u prijenosu, p. 56.

${ }^{121}$ Quoted in ibid..

122 'Kulturna politika ..., p. 6.

123 'Na račun tako imenovane visoke mode se vedno bolj uveljavlja konfekcija', Primorski dnevnik, 18 November 1971, p. 4.
} 
majority 'to which film represents entertainment, relaxation'. ${ }^{124}$ The interviewee also emphasized the cinema's attempt to educate the less demanding cinema-goers by occasionally introducing 'more challenging films', with the aim of 'consciously educating those viewers who do not want to think too much while watching [the film]'. By doing so, the chain of cinemas was in his view able to respond both to the demands of the market and to the demands of film art.

A factor that worked against the wholesale rejection of mass produced artifacts, consumer culture and Western formats was the fact that Yugoslav leaders have learned to exploit the popularity of these cultural forms to their own advantage, and used them to boost their standing abroad as well as to attract popular support at home. The media treatment of Tito's encounters with Hollywood actors and films is particularly telling in this respect. When visiting the United States in 1971, the Yugoslav leader attended a formal welcome organized by the Los Angeles mayor, whose guest list included several Hollywood stars. Novi list found this event important enough to mention it on its cover page, and introduced it with a telling title: 'Hollywood stars express admiration for Tito'. The main emphasis of the report was on actors' responses to Tito's presence; the reporter mentioned that 'several famous celebrities were glad Tito visited the U.S.A,' and 'did not hide their admiration for Tito's personality'. ${ }^{125}$ 1971 was also the year when Richard Burton agreed to play the role of Tito in a dramatization of the Battle of Sutjeska, one of the key World War Two confrontations between the Axis powers and the Yugoslav partisans. While the film was being shot, the actor and his wife Liz Taylor were constantly followed by the Yugoslav paparazzi, who were particularly keen on obtaining any evidence of Burton's admiration for Tito and Yugoslavia. One characteristic report of this kind included Burton's comments about Yugoslavia's

\footnotetext{
124 'Med filmsko umetnostjo in tržnimi zahtevami', Primorske novice, 07 May 1971, p. 7.

125 'Holivudske zvijezde dive se Titu', Novi List, 03 November 1971, p. 1.
} 
'fantastic landscape' and Tito's heroism, and mentioned Liz Taylor's alleged interest in acting in a film about Yugoslavia. ${ }^{126}$ Evidently, the Hollywood stars were not the only objects of fascination in this context; rather, they served to boost popular support for Tito and Yugoslavia. If even Hollywood actors admired Tito, why should anyone in Yugoslavia have doubts about his leadership?

An additional aspect that contributed to the acceptance of popular culture in the Yugoslav northwest was the booming tourism industry. In the 1960 s alone, the number of foreign visitors to Yugoslavia increased from one to almost five millions per year. ${ }^{127}$ Revenues from tourism along the Adriatic coast were mushrooming, and the local population was keen to invest in further improvements of tourist facilities, including the organization of a wider range of cultural events targeted at foreign visitors. The local press provides ample evidence of how important popular culture was in boosting the leisure industry. During the summer months, one of the key criteria used for assessing the quality of cultural events was their attractiveness to Western tourists, and reporters often commended the organizers for staging a particularly well attended concert, or criticized them for failing to offer an attractive enough choice of cultural events during the tourist season. ${ }^{128}$ This can be seen as a local version of a more widespread tendency to use popular culture as a means of promoting Yugoslavia internationally, and presenting it as an exceptionally 'liberal' and 'progressive' socialist country..$^{129}$

\footnotetext{
126 'Mi spiano scettici, mi squadrano sospettosi', La Voce del Popolo, 3 September, 1971, p. 5.

${ }^{127}$ Duda, U potrazi za blagostanjem.

${ }^{128}$ E.g. 'Turismo senza cultura', La Voce del Popolo, 03 September, p. 6; L. Ostrouška, 'Gostovanje ansambla Mihe Dolžana na Obali', Primorske movice, 07 May 1971, p. 7.

${ }^{129}$ This tendency was visible in the international promotion of Yugoslav popular music in Eastern Europe. See Dean Vuletic, 'Sounds like America: Yugoslavia's Soft Power in Eastern Europe', paper presented at the conference Divided Dreamworlds - The Cultural Cold War in East and West, September 2007, Utrecht.
} 
On the whole, the discourses about culture in 1971 were marked by a diversity of normative principles, and some of them - most notably the emphasis on culture as a means of national preservation, and the perception of art as apolitical - crossed the line of what was deemed acceptable by the LCY. In contrast to 1947 , the discursive uses of these normative ideals were to a large extent aimed at establishing hierarchical distinctions within 'our culture' rather than at positioning 'our' culture in historical and geopolitical terms. The only exception to this rule was the coverage of popular culture, yet even here, the geopolitical sense of the Yugoslav self did not emerge through explicit positioning of Yugoslav culture with respect to 'the East' and 'the West', but was created more indirectly and implicitly, for instance by constructing Western entertainment as attractive yet somehow alien and threatening, by reporting on Western expressions of admiration for Yugoslavia, by emphasizing the importance of 'impressing' foreign visitors, and by saying virtually nothing about cultural developments elsewhere in the world. Such vague and indirect deictic positioning of the 'here' and 'there, 'us' and 'them' had its counterpart in the tendency to associate 'our' culture primarily to individual national cultures rather than the Yugoslav culture at large.

To put it differently, if the coverage in 1947 was clearly marked by the Cold War confrontation, and oriented towards marking the distinctiveness of Yugoslav culture vis-à-vis its geopolitical and historical others, the coverage in 1971 was oriented primarily to internal struggles and hierarchies. At the same time, the way in which these internal struggles were framed and categorized - exemplified in the use of organicist metaphors and the emphasis on national preservation rather than change - served to present them as natural and rooted in history, thereby obscuring the fact that they were a recent product of changing cultural practices and policies, and of the journalistic discourse itself. Unlike the progress-centered 
discourse of 1947, which neglected continuities with the past, the discourse of 1971 had the exact opposite effect, namely of obscuring change by presenting it as part of nature and history. It is precisely in this discursive context that the Cold War binaries of East and West would re-enter the language of the Yugoslav mass media in the late 1980s and the early 1990s, when they would be used to discursively unravel Yugoslav culture from within by distinguishing between the culturally 'Western' republics of Slovenia and Croatia, and the culturally 'Eastern' or 'Balkan' rest of the country. ${ }^{330}$ At that point, the whole of the Yugoslav past emerged as a harmful deviation from the prescribed course of modernization, and as an unnatural, forced marriage of the East and the West.

\section{Conclusions}

The conclusions drawn in this paper have important implications for our understanding of the Cold War, especially for any research that aims to unpack the role of discourse, language, ideology and culture in this historical period. First, our analysis suggest that the categories and distinctions used in narrating the cultural history of the Cold War - East and West, class and nation, socialism and capitalism, elite and mass culture etc. - should be approached with caution. Any application of these categories that does not take into account their shifting meanings and practical uses, runs the risk of missing the gap that separated subjective representations from political, economic and social structures they were embedded in and helped sustain. As shown in the paper, the particular discursive uses of Cold War categories and distinctions obscured their own role in creating - rather than merely describing - the realities of Yugoslav culture, and should therefore be subjected to critical scrutiny rather than taken at face value. Such critical investigation of discourse is particularly important when

\footnotetext{
${ }^{130}$ E.g. Nicole Lindstrom and Maple Razsa, 'Balkan is Beautiful: Balkanism in the Political Discourse of Tuđman's Croatia', East European Politics and Societies, Vol. 18, No. 4, pp. 628-50 (2004).
} 
dealing with categories and normative distinctions that continue to circulate in journalistic and scholarly discourse today, and have in the meantime accrued new meanings and became embedded in different social structures. If used unreflexively, such categories and distinctions can easily lead us to confuse the hopes and regrets of today with the realities and concerns of the past.

At the same time, we should also resist the temptation of dismissing Cold War discourse as a mere myth that has nothing to do with the everyday realities and concerns at the time, and is hence unworthy of analysis. This would not only miss the constitutive role of discourse in shaping and sustaining Cold War realities, but also invite a rather misleading description of the period, organized around contrasts between myth and reality, official ideology and private narratives, oppression and resistance. Such a description would do little to explain why individual social actors were willing to overlook the mismatch between Cold War discourse and the realities they lived in, and even appropriate elements of this discourse as fully adequate descriptions of their lifeworlds. In addition, a simplistic contrast between myth and reality also runs the risk of ascribing too much weight to discourses that diverged from officially endorsed narratives and categories, and even treat them as somehow more 'real' than official ones. Such an understanding can come uncomfortably close to currently popular accounts of the Cold War, and risks becoming entangled in contemporary political struggles and divided memories of the period. 